\title{
A STUDY OF THE DELTAIC COAST MORPHOMETRY OF RIVER PINIOS IN RELATION TO ITS HYDRO- \& SEDIMENT DYNAMICS
}

\author{
Foutrakis P. ${ }^{1}$, Poulos S. ${ }^{1}$, Maroukian H. ${ }^{1}$, and Livaditis G. ${ }^{1}$ \\ ${ }^{l}$ National and Kapodistrian University of Athens, Faculty of Geology and Geoenvironment, \\ Department of Geography \& Climatology, Panepistimioupoli, Zografou 15784, Athens, Greece
}

\begin{abstract}
This paper refers to the study of the morphodynamic processes, on a seasonal basis, in the river delta of Pinios (Greece) with the application of the discharge effectiveness index (Ef) -which associates the water discharge (D) with the wave power $(P)$ - and the estimation of the potential longshore sediment transport $(\mathrm{Ql})$. The delta is characterised according to the classification proposed by Galloway (1975) and revised by Briggs et al (1997), as wavelfluvial dominated type of delta, having a cuspate shape like the deltas of San Francisco and Rhone. Wave processes are dominant during summer-autumn period (low values of Ef) and river processes are important in winter and spring (high values of Ef). The total potential longshore sediment transport is northwards and more intensive in the region to the south of its current mouth.
\end{abstract}

Key words: discharge effectiveness index, Holocene, Aegean Sea.

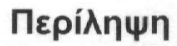

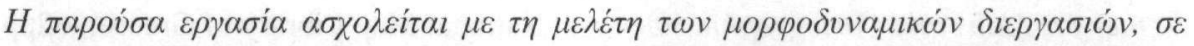

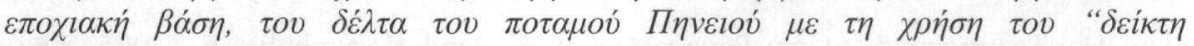

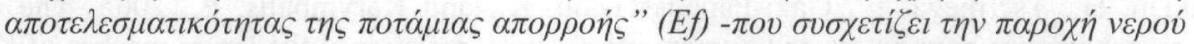

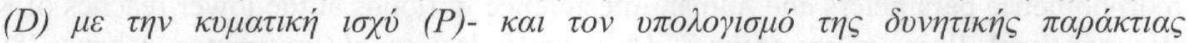

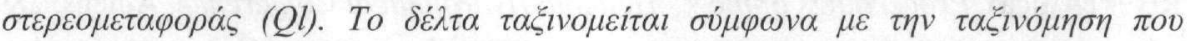

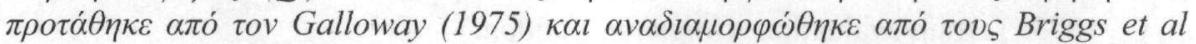

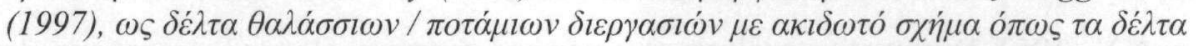

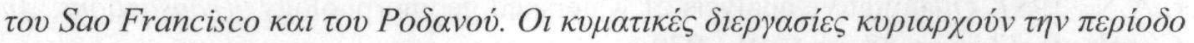

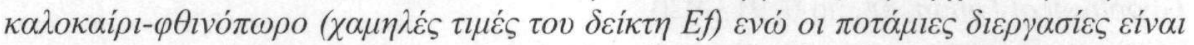

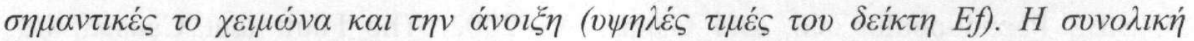

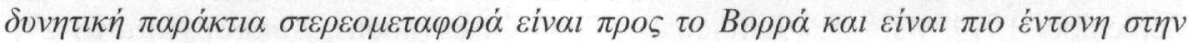

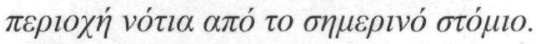

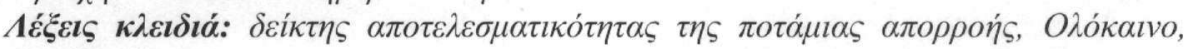

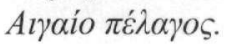

\section{Introduction}

Delta shapes and configurations adjoining seas and oceans are the result of fluvial-marine interaction; this involves factors such as water/sediment discharge, wave activity, tidal range, 
winds, and nearshore currents (Wright 1985). For the analysis of the delta systems, a trilinear classification (fluvially, wave and tidally dominated) was derived by Galloway (1975) and revised by Briggs et al. (1997).

In the case of Greek deltas, such as Pinios, where the marine environment is microtidal, delta formation is a result of the interaction between fluvial and wave processes, where the quantitative inter-relationship is given by the "discharge effectiveness index" (Wright and Coleman 1973). The higher the index is, the greater the ability of the river to form its own delta geometry. Moreover, (for the case of Greek river deltas) the seasonal variations of water and sediment discharge can also play a significant role in delta formation.

The aim of the present contribution is to describe qualitatively and quantitatively the morphometry of the deltaic coast of R. Pinios, on the basis of Galloway's (1975) classification, the Wright and Coleman's (1973) discharge effectiveness index and the potential longshore sediment transport on a seasonal basis. The delta of the R. Pinios (drainage basin area $10.850 \mathrm{~km}^{2}$ ) was chosen as representative of medium sized Mediterranean river systems e.g. Souman (Algeria) (drainage basin area $8.500 \mathrm{~km}^{2}$ ), Goksu (Turkey) (drainage basin area $10.561 \mathrm{~km}^{2}$ ), Arno (Italy) (drainage basin area $8.183 \mathrm{~km}^{2}$ ) and Vijose (Albania) (drainage basin area $6.706 \mathrm{~km}^{2}$ ) which have developed in coastal zones exposed to the open sea wave activity.

\section{The Study Area}

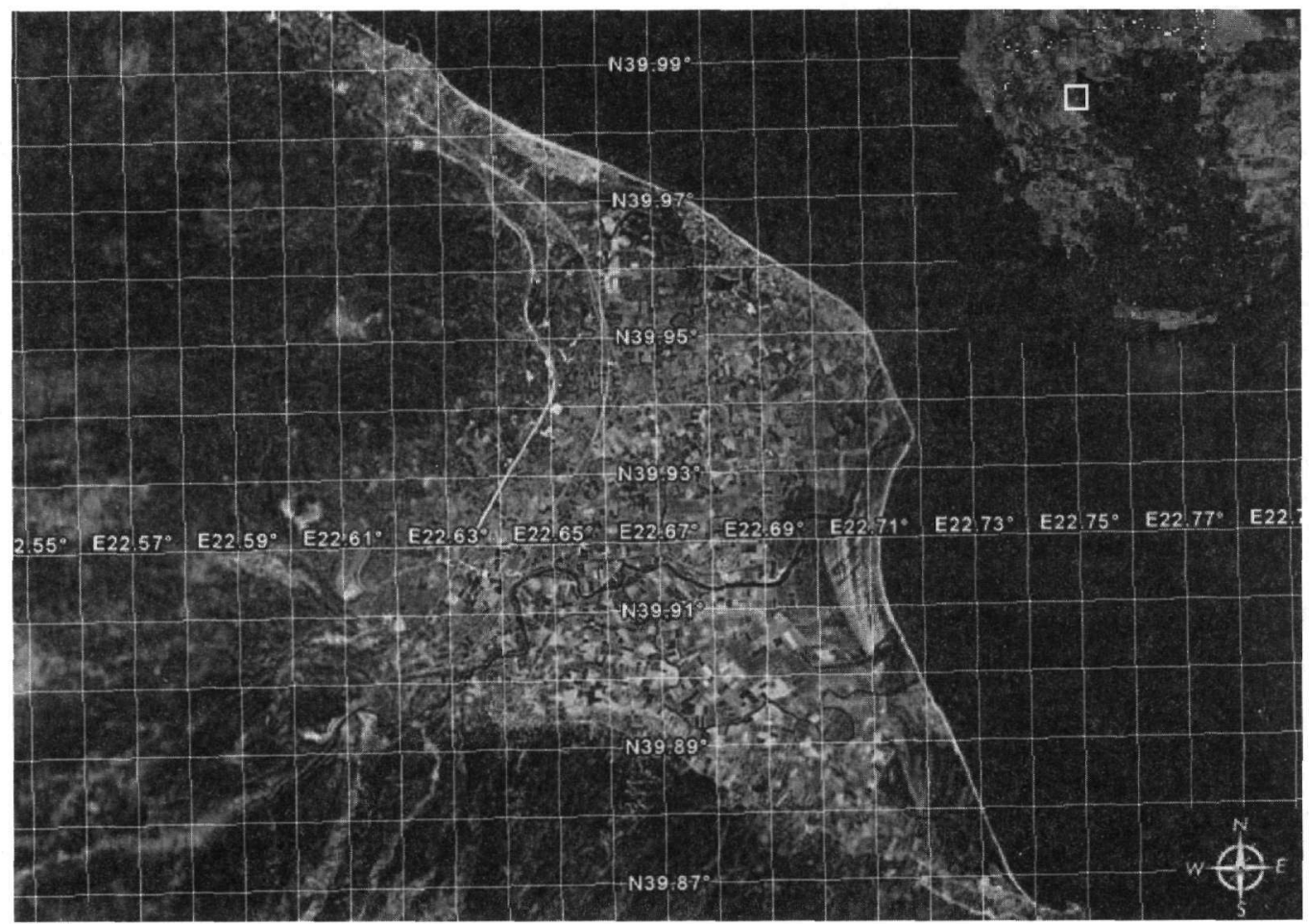

Figure 1 - Location of the Pinios river delta (original picture from Google Earth 2006)

The R. Pinios drains into the southern part of outer Thermaikos Gulf, in the northwestern part of the Aegean sea. The length of R. Pinios is about $257 \mathrm{~km}$ and the total catchment area is about $10.850 \mathrm{~km}^{2}$, most of it having elevations lower than $300 \mathrm{~m}$, while the higher areas are restricted to its northern boundary where heights are in excess of $1.500 \mathrm{~m}$. As far as the deltaic area is concerned, it is about $69 \mathrm{~km}^{2}$. 
The lithology of the catchment area consists of alluvial and clastic deposits $(68 \%)$, calcareous formations (11,5\%), metamorphic rocks (15,2\%) and igneous rocks (5,3\%) (Poulos et al. 1996).

The climate of the nearshore part of the R. Pinios catchment can be described generally as "Mediterranean" while its central area is closer to the "continental" type with less rainfall and larger seasonal variations in air temperature.

The mean monthly water discharge of the R. Pinios is about $81 \mathrm{~m}^{3} / \mathrm{s}$ (Therianos 1974) while the mean monthly discharges of the river are shown in Table 1. According to Poulos et al (1996) the annual suspended sediment load for R. Pinios accounts to $5,9 \times 10^{6} \mathrm{t}$.

Table 1 - Water Discharge in $\mathrm{m}^{3} / \mathrm{s}$ (Therianos 1974)

\begin{tabular}{|c|c|c|c|c|c|c|c|c|c|c|c|r|}
\hline J & F & M & A & M & J & J & A & S & O & N & D & AVERAGE \\
\hline 161 & 160 & 115 & 93 & 71 & 32 & 12 & 11 & 25 & 59 & 61 & 171 & 80.92 \\
\hline
\end{tabular}

Due to the lack of monthly (seasonal) sediment flux measurements for the R. Pinios, its monthly variation of sediment load is deduced from the comparison between the measured water discharges of R. Pinios with the monthly values of water and sediment discharges of R. Aliakmon (Table 2), which is located to the north of R. Pinios, having a part of their catchment boundary in common. Moreover, both rivers having their catchments to the east of the Pindos mountain chain are characterized by similar lithological, climatic and hydrological conditions (Mimikou 1982).

Table 2- Monthly water discharge of the R. Aliakmon (D in $\mathrm{m}^{3} / \mathrm{s}$ ) (Therianos 1974) and suspended sediment load ( $\mathrm{S} \mathrm{x10^{6 }}$ in tones) (data made available by the Public Power Corporation)

\begin{tabular}{|r|c|c|c|c|c|r|r|r|r|r|r|r|r|}
\hline & J & F & M & A & M & J & J & A & S & O & N & D & AVER. \\
\hline D & 116 & 121 & 137 & 102 & 77 & 47 & 29 & 21 & 22 & 26 & 62 & 113 & 72,75 \\
\hline S & 8.04 & 12.84 & 7.00 & 4.41 & 1.85 & 0.35 & 0.21 & 0.03 & 0.15 & 0.62 & 6.17 & 11.30 & 4.41 \\
\hline
\end{tabular}

The mean tidal range in Thermaikos is $19 \mathrm{~cm}$ (Tsimplis 1994). The delta area is exposed to relatively high wave attack, due to the long fetches available from the north (about $105 \mathrm{~km}$ ), the northeast $(60 \mathrm{~km})$, the east $(123 \mathrm{~km})$ and southeast $(275 \mathrm{~km})$. The bottom topography of the receiving basin is highly steep with slopes of $10 \%$ and the depth overcomes $50 \mathrm{~m}$ at about $2,5 \mathrm{~km}$ from the shoreline (Poulos et al. 1996). The sediments of the receiving basin have a zonal distribution, because of the high values of wave power, from sand to clay and mud.

\section{Materials and Methods}

For the morphometric classification of the delta of R. Pinios, the satellite image from Google Earth (Fig. 1) and the classification proposed by Galloway (1975) and modified later by Briggs et al. (1997) have been used.

In order to describe quantitatively the relationship between river discharge and wave power on a seasonal basis, the "discharge effectiveness index" (Ef), as proposed by Wright and Coleman (1973), and given by Equation 1, has been utilised:

\section{Equation 1 - Discharge Effectiveness Index}

Ef $=\frac{D}{b} \times \frac{1}{P}$

where, D is the river discharge (in $\mathrm{m}^{3} / \mathrm{s}$ ), $\mathrm{b}$ is the channel width at the river mouth (in $\mathrm{m}$ ), and $\mathrm{P}$ is the wave power per unit wave crest (in $\mathrm{W} / \mathrm{m}$ ). 
Seasonal river water discharges were abstracted from Therianos (1974) and river mouth length was measured on the topographic chart Rapsani 1:50.000 (Institute for Geology and Mineral Exploration)

Wave power was calculated in offshore conditions and at breaking zone, using the Equation 2 (CERC, 2000):

\section{Equation 2 - Wave power}

$$
P=\frac{1}{8} \times \rho \times g \times H^{2} \times C g
$$

where, $\mathrm{P}$ is measure in $\mathrm{W} / \mathrm{m}, \mathrm{Cg}$ is the group velocity of the waves in $\mathrm{m} / \mathrm{sec}, \mathrm{H}$ is the wave height in $\mathrm{m}, \rho$ is the density of the sea water in $\mathrm{kg} / \mathrm{m}^{3}$ and $\mathrm{g}$ is the acceleration due to gravity in $\mathrm{m} / \mathrm{s}^{2}$.

Wave characteristics required for the calculation of wave power offshore have been estimated using wind data from Wind and Wave Atlas (Athanasoulis and Skarsoulis 1992) and wave forecasting equations as proposed from Coastal Engineering Research Centre (CERC 2000), while wave characteristics required for the calculation of wave power at the breaking zone have been estimated using the numerical model CEDAS (Coastal Engineering Design \& Analysis System), with the bathymetry obtained from the topographic chart Rapsani 1:50000 (Institute for Geology and Mineral Exploration).

The derived seasonal wave power has been multiplied by the corresponding seasonal percentage of wind duration for each fetch direction, was used in order to calculate the actual wave power for each season.

For the estimation of the longshore sediment transport, which affects delta morphometry, we used the seasonal potential longshore transport rate Q1 that is given by the Equation 3 (CERC 2000):

\section{Equation 3 - The potential longshore transport rate}

$$
Q l=\frac{0,39 P l_{b}}{g \times(\sigma-\rho) \times \alpha^{\prime}} \quad \text { in }\left(\mathrm{m}^{3} / \mathrm{sec}\right)
$$

where, Ql is measured in $\mathrm{m}^{3} / \mathrm{s}, \mathrm{g}$ is the acceleration due to gravity in $\mathrm{m} / \mathrm{s}^{2}$ the $\sigma$ and $\rho$ are the densities of sediment $\left(2650 \mathrm{~kg} / \mathrm{m}^{3}\right)$ and saltwater $\left(1025 \mathrm{~kg} / \mathrm{m}^{3}\right)$ respectively, $\mathrm{a}=0,6$ (representing the sand porosity) and $\mathrm{Pl}_{\mathrm{b}}$ is the longshore energy flux factor given by the relation:

\section{Equation 4 - Longshore wave power}

$$
P l_{b}=0,0884 \times \rho \times g^{3 / 2} \times H_{b}^{5 / 2} \times \sin 2 \alpha_{b}
$$

where, $\alpha_{b}$ is the angle between the wave crest and the coastline and $\mathrm{H}_{\mathrm{b}}$ is the wave height at the breaking zone in $\mathrm{m}$; the latter are provided by the CEDAS.

\section{Results and Discussion}

The delta of R. Pinios is cuspate in shape (Fig. 1). being similar to that of river San Francisco and Rhone. Thus, on the basis of its morphometry and according to Galoway's (1975) classification, wave energy is the dominant process in its formation while river processes (water and sediment fluxes) also play an imp rtant role. The seasonal variability in water discharge of R. Pinios is analogous to that of R. t won (Table 3; Fig. 2), both presenting their highest values in winter. According to Figure 2 th nal sediment load in Pinios river is expected to be similar, as far as the seasonal variations 
values in summer and autumn (about $14,2 \%$ of the total) and maximum values in winter and spring (about $85,8 \%$ of the total) following the variation of water discharge.

Table 3 - Seasonal variation of water (D) and suspended sediment (S) discharge of the rivers Pinios and Aliakmon

\begin{tabular}{|l|l|r|r|r|r|r|}
\hline & & SPRING & SUMMER & AUTUMN & WINTER & TOTAL \\
\hline PINIOS & $\mathrm{D}\left(\mathrm{m}^{3} / \mathrm{s}\right)$ & 93.00 & 18.33 & 48.33 & 164.00 & 323.66 \\
\hline \multirow{2}{*}{ ALIAKMON } & $\mathrm{D}\left(\mathrm{m}^{3} / \mathrm{s}\right)$ & 83.88 & 14.73 & 22.14 & 84.58 & 20.33 \\
\cline { 2 - 7 } & $\mathrm{S}\left(\mathrm{x} 10^{6} \mathrm{t}\right)$ & 4.42 & 0.20 & 2.31 & 10.73 & 17.66 \\
\hline
\end{tabular}

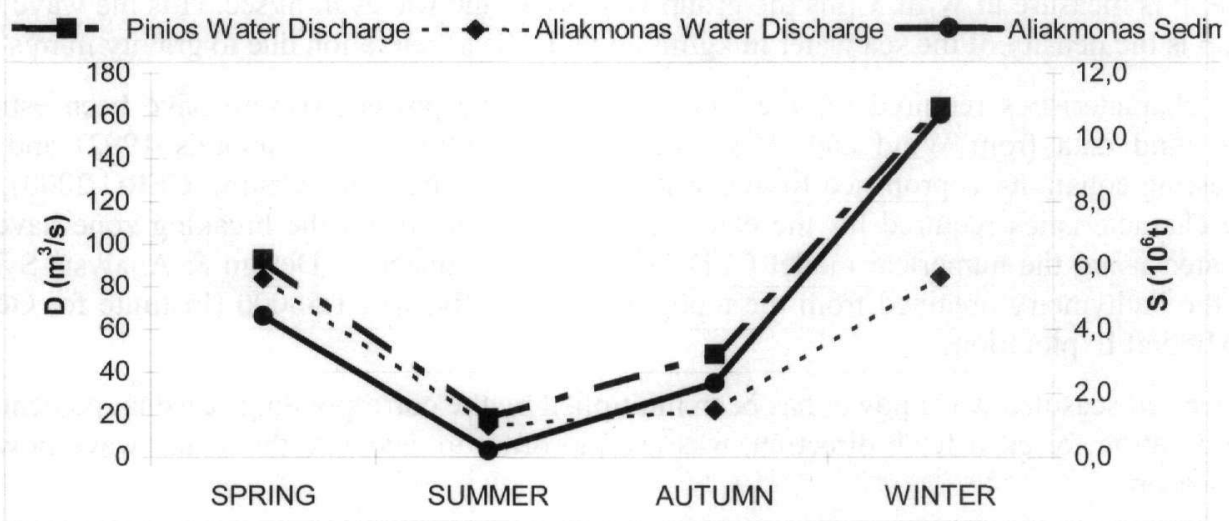

Figure 2 - Seasonal variation in water discharge ( $D$ in $\mathrm{m}^{3} / \mathrm{s}$ ) of rivers Pinios and Aliakmonas and sediment load $\left(\mathrm{S} \times 10^{6}\right.$ in $\left.\mathrm{t}\right)$ of river Aliakmonas

Seasonal water discharges, derived wave power and calculated effectiveness indices (offshore and at the breaking zone) are listed in Table 4 and presented schematically in Figures 3 and 4 . As it can be seen wave power is reduced from offshore to the breaking zone while discharge effectiveness index is increased. Moreover, high values of wave power occur in spring, autumn and winter.

The Ef values of river Pinios in comparison with other cuspate shaped world deltas like San Francisco $\left(\mathrm{Ef}=6.27 \times 10^{-3}\right.$; Wright and Coleman 1973) are higher due to the different spatial scale of these two systems. Therefore, successful comparisons can be made between analogous river/delta systems, as for example between the rivers Pinios and Aliakmon, (offshore $\mathrm{Ef}=2.40 \times 10^{-}$ 2; from Poulos et al. 1993) with the latter being characterized as fluvial dominated, as it has being formed in the semi-enclosed embayment of the inner Thermaikos Gulf.

Table 4 - Seasonal water discharges (D), wave power (P; per unit crest width) and discharge effectiveness indices (Ef) for the R. Pinios

\begin{tabular}{|l|r|r|r|r|r|}
\hline & SPRING & SUMMER & AUTUMN & WINTER & AVERAGE \\
\hline $\mathrm{D}\left(\mathrm{m}^{3} / \mathrm{s}\right)$ & 93.00 & 18.33 & 48.33 & 164.00 & 80.92 \\
\hline $\mathrm{P}(\mathrm{W} / \mathrm{m})$ offshore & 89.99 & 52.10 & 304.97 & 107.94 & 138.75 \\
\hline $\mathrm{Ef}\left(\mathrm{x} 10^{-2}\right)$ offshore & 0.47 & 0.16 & 0.07 & 0.69 & 0.27 \\
\hline $\mathrm{P}(\mathrm{W} / \mathrm{m})$ at breaking zone & 56.14 & 15.57 & 95.23 & 39.94 & 51.72 \\
\hline$E f\left(x 10^{-2}\right)$ at breaking zone & 0.75 & 0.54 & 0.23 & 1.87 & 0.71 \\
\hline
\end{tabular}




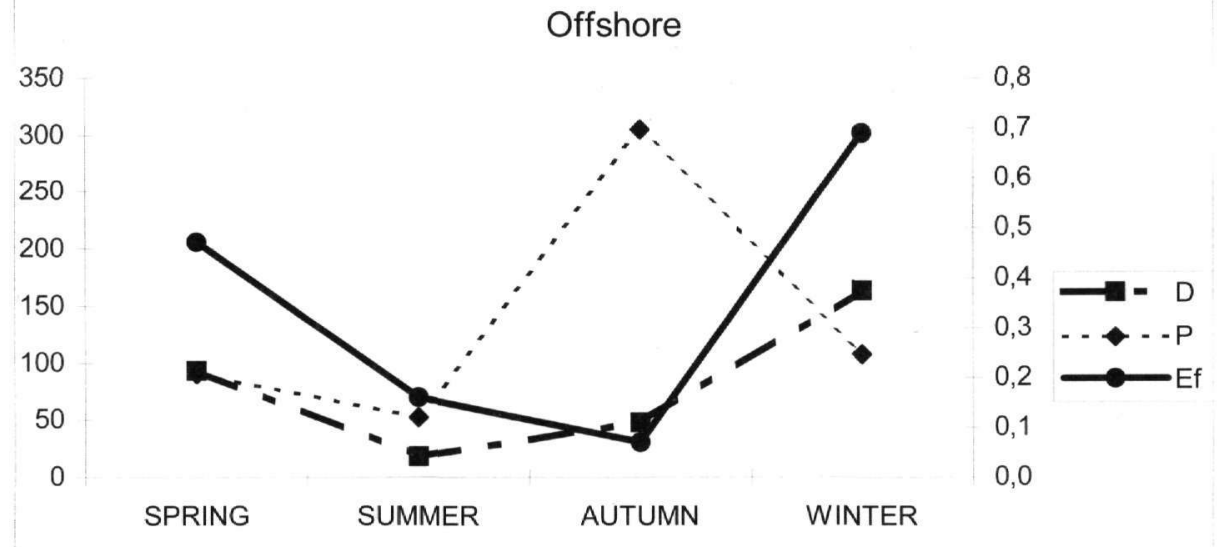

Figure 3 - Seasonal variation in water discharge (D in $\left.\mathrm{m}^{3} / \mathrm{s}\right)$, wave power $(\mathrm{P}$ in $\mathrm{W} / \mathrm{m})$ and discharge effectiveness index (Ef) in offshore conditions (In the left column is the scale for D and $P$ while in the right column is the scale for $\mathbf{E f}$ )

\section{Breaking Zone}

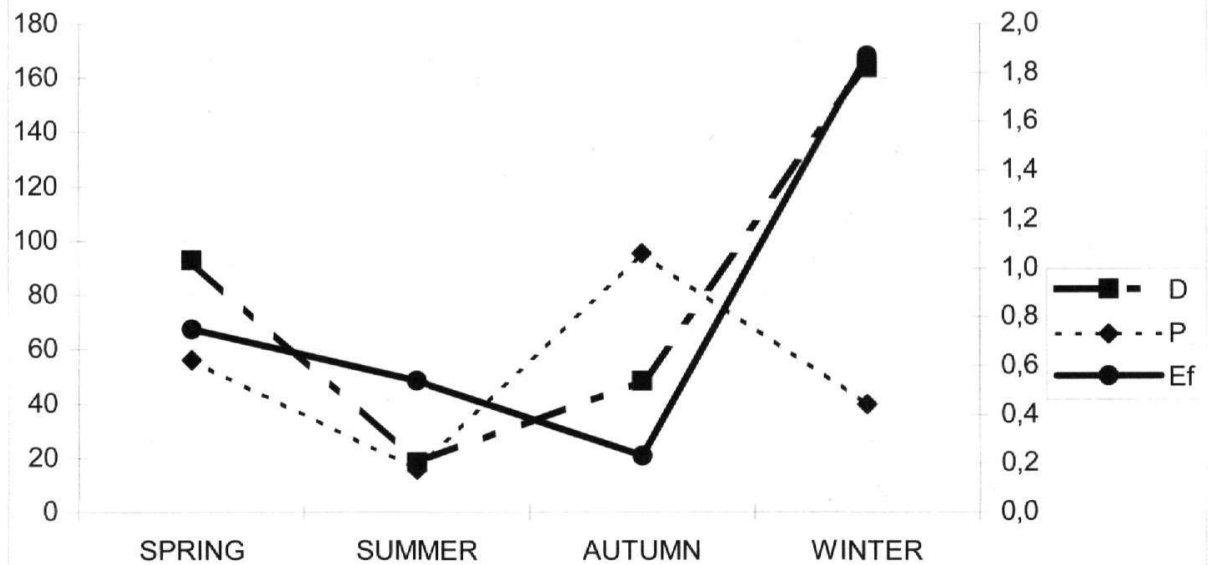

Figure 4 - Seasonal variation in water discharge (D in $\mathrm{m} 3 / \mathrm{s})$, wave power $(\mathrm{P}$ in $\mathrm{W} / \mathrm{m})$ and discharge effectiveness index (Ef), at breaking zone (In the left column is the scale for D and $P$ while in the right column is the scale for $\mathbf{E f}$ )

In spring, river discharge levels and wave power values (Figure 4) are very high $\left(93.00 \mathrm{~m}^{3} / \mathrm{s}\right.$ and $56.14 \mathrm{~W} / \mathrm{m}$ respectively) decreasing to their minimum during summer $\left(18.33 \mathrm{~m}^{3} / \mathrm{s}\right.$ and $15.57 \mathrm{~W} / \mathrm{m}$ respectively) with analogues reduction of the discharge effectiveness index. The latter reaches its minimum value in autumn $\left(0.23 \times 10^{-2}\right)$ because of the combination of high wave power $(95.23$ $\mathrm{W} / \mathrm{m})$ and low water discharge $\left(48.33 \mathrm{~m}^{3} / \mathrm{s}\right)$. In winter the discharge effectiveness index reaches its maximum $\left(1.87 \times 10^{-2}\right)$ due to the high river discharge $\left(164.00 \mathrm{~m}^{3} / \mathrm{s}\right)$. Thus, in the period from winter to spring, the corresponding high values of Ef suggest deltaic progradation while in the period summer-autumn the low values of Ef combined with the increased values of wave power, which are the highest in autumn, indicate that river delta is dominated by wave induced processes and the associated nearshore sediment transport. 
The potential longshore sediment transport rate Q1 has been calculated for the four regions of the deltaic coast, which have been defined according to their orientation (see Fig. 5). The seasonal values of Q1 are given on Table 5 .

Table 5-Potential longshore transport rate $\mathrm{Ql}\left(\mathrm{x}_{10}{ }^{3}\right) \mathrm{m}^{3} /$ season $(+\operatorname{transport}$ from $\mathrm{N}$ to $\mathrm{S})$

\begin{tabular}{|c|r|r|r|r|r|}
\hline REGION & \multicolumn{1}{|c|}{ SPRING } & \multicolumn{1}{|c|}{ SUMMER } & \multicolumn{1}{|c|}{ AUTUMN } & \multicolumn{1}{c|}{ WINTER } & \multicolumn{1}{c|}{ SUM } \\
\hline 1 & 99.37 & 110.86 & 478.28 & 87.06 & 775.57 \\
\hline 2 & -350.21 & -1.23 & -527.23 & -222.29 & -1100.96 \\
\hline 3 & -1187.78 & -457.20 & -2020.02 & -971.14 & -4636.14 \\
\hline 4 & -20.76 & -16.12 & -87.30 & -38.27 & -162.44 \\
\hline SUM & -1459.38 & -363.68 & -2156.27 & -1.144 .64 & -5123.97 \\
\hline
\end{tabular}

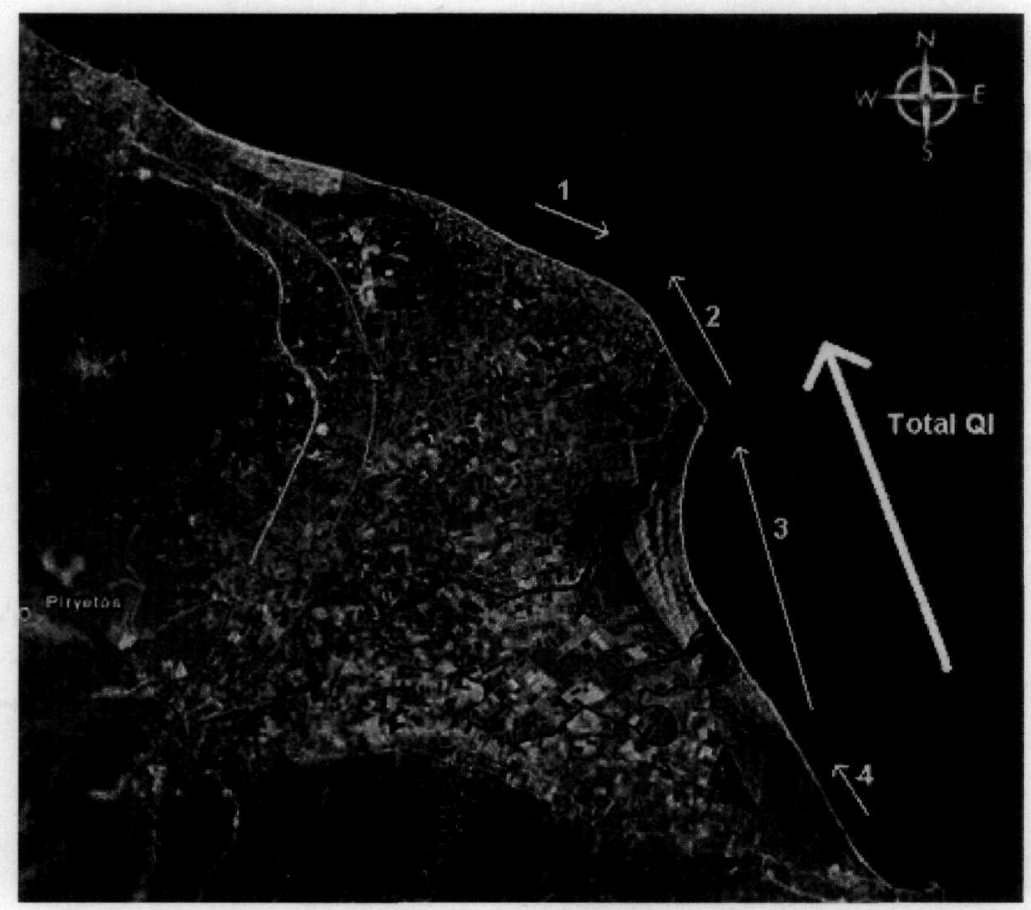

Figure 5 - Direction of the potential longshore transport in regions $(1, \ldots 4)$

In region 1 the potential longshore transport is from NW to SE while in regions 2,3 \& 4 the potential longshore transport is from $\mathrm{S}$ to $\mathrm{N}$; hence, the overall annual potential longshore transport is from the $\mathrm{S}$ to the N. Furthermore, this northward direction of the potential longshore transport is preserved at all the seasons reaching the highest value in autumn (when Ef reaches also its highest value). The above is in agreement with the morphometry of the area near the delta mouth where the northern part is more developed in comparison to the southern part, in which a shoreline retreat during the last decades has been reported by Stournaras and Galani (1995); this retreat has been attributed to human activities and the natural abandoned of the old river mouth in the 1930's from a southern position (village Stomion) to the position that it is today.

\section{Conclusions}

The shape of the deltaic coast of R. Pinios is cuspate. Its morphometry is attributed primarily to wave and secondarily to riverine processes. Deltaic progradation takes place mostly in winter and spring. 
The overall longshore sediment transport is directed to the north reaching its highest value during autumn and spring being more pronounced in the region located to the south of the modern river mouth.

\section{References}

Athanasoulis, G.A., and Skarsoulis, P.K., 1992. Wind and Wave Atlas of the Northeastern Mediterranean Sea, Hellenic Navy General Staff, Athens.

Briggs, D., Smithson, P., Addison, K., and Atkison, K., 1997. Fundamentals of the Physical Environment, Second Edition, Routledge, London.

CERC, (Coastal Engineering Research Centre), 2000. Coastal Engineering Manual, US Army Corps of Engineers, Washington DC 21314.

Galloway, W.E., 1975. Process framework for describing the morphological and stratigraphic evolution of deltaic depositional systems. In M.L. Broussard (ed.), Deltas, Models for Exploration (2nd Ed.), Houston Geol. Soc., Houston, Texas, 87-98.

Mimikou, M., 1982. An investigation of suspended sediment rating curves in western and northern Greece, Hydrological Sciences Journal, 27, 3, 9/369-383.

Poulos, S.E., 1989. Deltaic sedimentation in the micro tidal environment of Greek waters, Unpublished PhD Thesis, Univ. of Wales, U.K., 434pp.

Poulos, S.E., Collins, M.B., and Evans, G.,1996. Water-sediment fluxes of Greek rivers, southeastern Alpine Europe: annual yields, seasonal variability, delta formation and human impact, Z.Gomorph, 40, 243-261.

Poulos, S.E., Collins, M.B., and Ke, X., 1993. Fluvial/wave interaction controls on delta formation for ephemeral rivers discharging into microtidal waters, Marine Letters, 13, 24-31.

Poulos, S.E., and Collins, M.B., 2002. Fluviatile sediment fluxes to the Mediterranean Sea: a quantative approach and the influence of dams. In S.J. Jones, and L.E. Frostick (eds), Sediment Flux to Basins: Causes, Controls and Consequences, Geological Society, London, Special Publications, 191, 227-245.

Stournaras, G., and Galani, X., 1995. Morphometric analysis of Pinios delta (Thessalia), Proceedings of the $4^{\text {th }}$ Panhellenic Geographical Symposium, Athens 1995, 333-347pp. (in Greek)

Therianos, A.D., 1974. The geographical distribution of river water supply in Greece, Bull. Geol. Soc. Greece, 11. (in Greek)

Tsimplis, M.N., 1994. Tidal Oscillations in the Aegean and Ionian Seas, Estuarine, Coastal and Shelf Science, 39, 201-208.

Wright, L.D, 1985. River deltas. In R.A. Davis (ed.), Coastal sedimentary environments, $2^{\text {nd }}$ ed. Springer Verlag, New York, 1-70.

Wright, L.D., and Coleman, J.M., 1973. Variations in morphology of major river deltas as functions of ocean wave and river discharge regimes, Bulletin of. The American Association. Of Petroleum Geologists, 57(2), 370-398.

www.GoogleEarth.com 